\title{
APPLICATION OF POLLUTION INDEXES FOR EVALUATION OF HEAVY METALS IN SOILS AND PLANTS CLOSE TO ABU - ZAABAL FERTILIZER FACTORIES - EGYPT.
}

\author{
Abd El-Salam Elwa. \\ Soil Chemistry and Physics Department, Water Resources and Desert Soils Division, \\ Desert Research Center, El-Matariya 11753, Cairo, Egypt. \\ Email- abdelsalamelwa33@yahoo.com \\ Key Wards: Abu -Zaabal . fertilizers - heavy metals . Quantification \\ pollution indexes .
}

\section{1- ABSTRACT}

Five profiles were selected from Abu -Zaabal area and five vegetable plants adjacent to soil profiles the profile number one is control profile and is located North west of the factory The others profile is located South east of the factory to determine the dangerous pollution which resulting from involved the study TF,BAF,SEPI and CPI of trace metals subject of study ( $\mathrm{Cr}, \mathrm{Cu}, \mathrm{Zn}, \mathrm{Co}$, and $\mathrm{Ni}$ ).Soil physical chemical properties of the studied soil are determined. Soil texture varied from sand to sandy loam. Soil reaction ranges from neutral to alkaline soil .The percent of O.M , $\mathrm{CaCO}_{3}$ and $\mathrm{ECe}$ are small values. The cationic and anionic (me/l) followed this order $\mathrm{SO}_{4}{ }^{--}>\mathrm{Ca}^{++}>\mathrm{HCO}_{3}{ }^{-}>\mathrm{Mg}^{++}>\mathrm{Na}^{+}$ $>\mathrm{Cl}^{-}>\mathrm{K}^{+}>\mathrm{CO}_{3}{ }^{--}$Total trace. metals contents in the soils . $(\mathrm{Zn}, \mathrm{Cu}, \mathrm{Ni}$, $\mathrm{Co}$, and $\mathrm{Cr}$ ) were determined by the Ionic Coupled Plasma (ICP), after digestion of the samples with a ternary acids mixture of $\mathrm{HNO}_{3}, \mathrm{H}_{2} \mathrm{SO}_{4}$ and $\mathrm{HClO}_{4}$. total trace elements are followed this order $\mathrm{Cr}>\mathrm{Cu}>\mathrm{Zn}>$ $\mathrm{Ni}>\mathrm{Co}$. The values are $118.25,91.32,67.95,39.51$ and $26.08 \mathrm{mg} / \mathrm{kg}$ receptively. According to the limits of total trace metals, Chromium is the highest element that is transmitted from soil and accumulate in vegetable plants and then enters directly or indirectly in food chain causing public health problems. Chemically extractable of trace metals contents in the studied soils $(\mathrm{Zn}, \mathrm{Cu}, \mathrm{Ni}, \mathrm{Co}$, and $\mathrm{Cr}$ ) followed this order $\mathrm{Cu}>\mathrm{Cr}>\mathrm{Zn}>\mathrm{Ni}>\mathrm{Co} .15 .64,15.46,12.40,8.26$, and $4.24 \mathrm{mg} / \mathrm{kg}$ receptively . The content of trace metals in grown vegetable plants in the studied soil followed this order $\mathrm{Zn}>\mathrm{Cu}>\mathrm{Cr}>\mathrm{Ni}>\mathrm{Co} .20 .58,43.78,33.24,9.32$ and 1.80 $\mathrm{mg} / \mathrm{kg}$ receptively. All trace metals above the permissible limits except Co and Ni metals. Given that $1>\mathrm{TF}>3,1>\mathrm{BAF}>3$ So occur translocation from soil to vegetables' and accumulates in them in this order. Onion 
plant > Egg plant > Faba bean> Potatoes fruit > Taro fruit. ranges between low, moderate and highly contamination.(SEPI ) In all trace metals varied from low to highly contaminated the soils (1> SEPI )>3). But in all profiles in the studied soil CPI <1.So the soils are low contamination by multi element except $\mathrm{Cu}$ with other metals are moderately contamination in the surface layer $(0-30 \mathrm{~cm})$ in the profile 3.where CPI $>1$ its $1.04 \mathrm{mg} / \mathrm{kg}$.

\section{2- INTRODACTION}

Heavy metals $\mathrm{Fe}, \mathrm{Mn}, \mathrm{Zn}, \mathrm{Cu}, \mathrm{Cr}$ and $\mathrm{Pb}$ were determined in selected soils of El-Gabal El-Asfar (GA): sewage irrigated lands, Mostorod (MD): soils around steel, battery and plumbing factories and AbouZabal (AZ):soils around fertilizer, sulfate of aluminum and potassium (alum,p) and ceramic factories. All experimental sites are located within Qalubiya Governorate. Soils were sandy loam in GA and AZ, clay loam in MD. Averages of total contents of above-mentioned metals (mg kg-1) were 5472, 163, 178, 6.5160 and 151, respectively; 17500, 228, 647, 58, 260 and 293 ; and 6333, 219, 358, 27, 155 and 266 for GA, AZ and MD soils, respectively. Variations were considerable within each site as well as between the three sites. Highest contamination was in MD soils followed by $\mathrm{AZ}$ then $\mathrm{GA}$ soils. Highest $\mathrm{Fe}, \mathrm{Zn}, \mathrm{Cr}$ and $\mathrm{Cu}$ within $\mathrm{AZ}$ soils were around the fertilizer factory followed by those around the (alum, p) factory then around the ceramic factory. For the highest $\mathrm{Pb}$, it was found in soils around the (alum, p) factory. There are evidences of pollution, particularly in the MD and AZ sites where the soils around industrial factories of steel, battery, fertilizers, smelters and ceramics exist (Noufal et al .,2015)

Determination of some heavy metals pollutants $(\mathrm{Cd}, \mathrm{Co}, \mathrm{Cr}, \mathrm{Pb}$, $\mathrm{Ni}$ ) released from selected industrial regions namely, Abu Zaabal - and $10^{\text {th }}$ of Ramadan was carried out.

Water, soil and plant samples were periodically collected from the selected areas during a period of one year . the concentration of the studied heavy metal pollutants was evaluated . In both regions .the results showed that the levels of heavy metal pollutants released from ABUZaabal region, in collected sample s, are higher than those released form $10^{\text {th }}$ of Ramadan city, except $\mathrm{Cr}$ in west water samples collected from the $10^{\text {th }}$ of Ramadan city, which was two folds higher than that of AbuZaabal region. This due to construction of new industrial cities according to the regulations and environmental laws. Also, the handling of the 
released pollutants at the $10^{\text {th }}$ of Ramadan region is easier than at $\mathrm{Abu}$ Zaabal region due to the governmental policy regarding collection of the different types of industrial wastes at selected are as the overall obtained results indicated that, although there are a lot of progresses regarding the handling of the released heavy metal pollutants in the 10 th of Ramadan region. The requirements for more efforts to overcome the problem of industrial pollutants at this region are still essential (Abou ElNour et al., 2004 ).

The accumulation of certain elements in vitally important media such as water, soil, and food is undesirable from the medical point of view. It is clear that the fertilizers vary widely in their heavy metals and uranium content. A shielded high purity germanium HPGe detector has been used to measure the natural concentration of $238 \mathrm{U}, 232 \mathrm{Th}$, and $40 \mathrm{~K}$ activities in the phosphate fertilizer and its components collected from Abu-Zaabal fertilizers and chemical industries in Egypt. The concentration ranges were 134.97-681.11 Bq kg(-1), 125.23-239.26 Bq $\mathrm{kg}(-1)$, and $446.11-882.45 \mathrm{~Bq} \mathrm{~kg}(-1)$ for $238 \mathrm{U}, 232 \mathrm{Th}$, and $40 \mathrm{~K}$, respectively. The absorbed dose rate and external hazard index were found to be from 177.14 to $445.90 \mathrm{nGy} \mathrm{h}(-1)$ and 1.03 to $2.71 \mathrm{nGy} \mathrm{y}(-1)$, respectively. The concentrations of 22 elements (Be, Na, Mg, Si, P, S, K, $\mathrm{Ca}, \mathrm{Ti}, \mathrm{V}, \mathrm{Cr}, \mathrm{Mn}, \mathrm{Fe}, \mathrm{Co}, \mathrm{Ni}, \mathrm{Cu}, \mathrm{Zn}, \mathrm{Sr}, \mathrm{Zr}, \mathrm{Mo}, \mathrm{Cd}, \mathrm{Ba}$ ) in the samples under investigation were determined by inductively coupled plasma optical-emission spectrometry (ICP-OES). The results for the input raw materials (rock phosphate, limestone and sulfur) and the output product as final fertilizer are presented and discussed (El-Bahi et al.,2004).

The concentrations of the heavy metals of the area between Anshas and Abu Zaabal, northeast Cairo, reflect the following results; the concentrations of Cadmium, Chromium and Lead in most samples are exceeding the international standards. The increase of concentration of heavy metals reflects an increase of pollution in the study area due to mainly industrial activities Gad, et al.,(2018 )

\section{3- MATERIALS AND METHODS}

\section{3/1 -Soil Sampling and Preparation for studies.}

Five Soil profiles selected from the study area (Abu - Zaabal) were selected. These profiles were dug deep down to variable depth, soil samples of the subsequent layers in each soil profile were carefully collected in polyethylene bags using ultra clean spades with no possible contamination in Figure (1). 

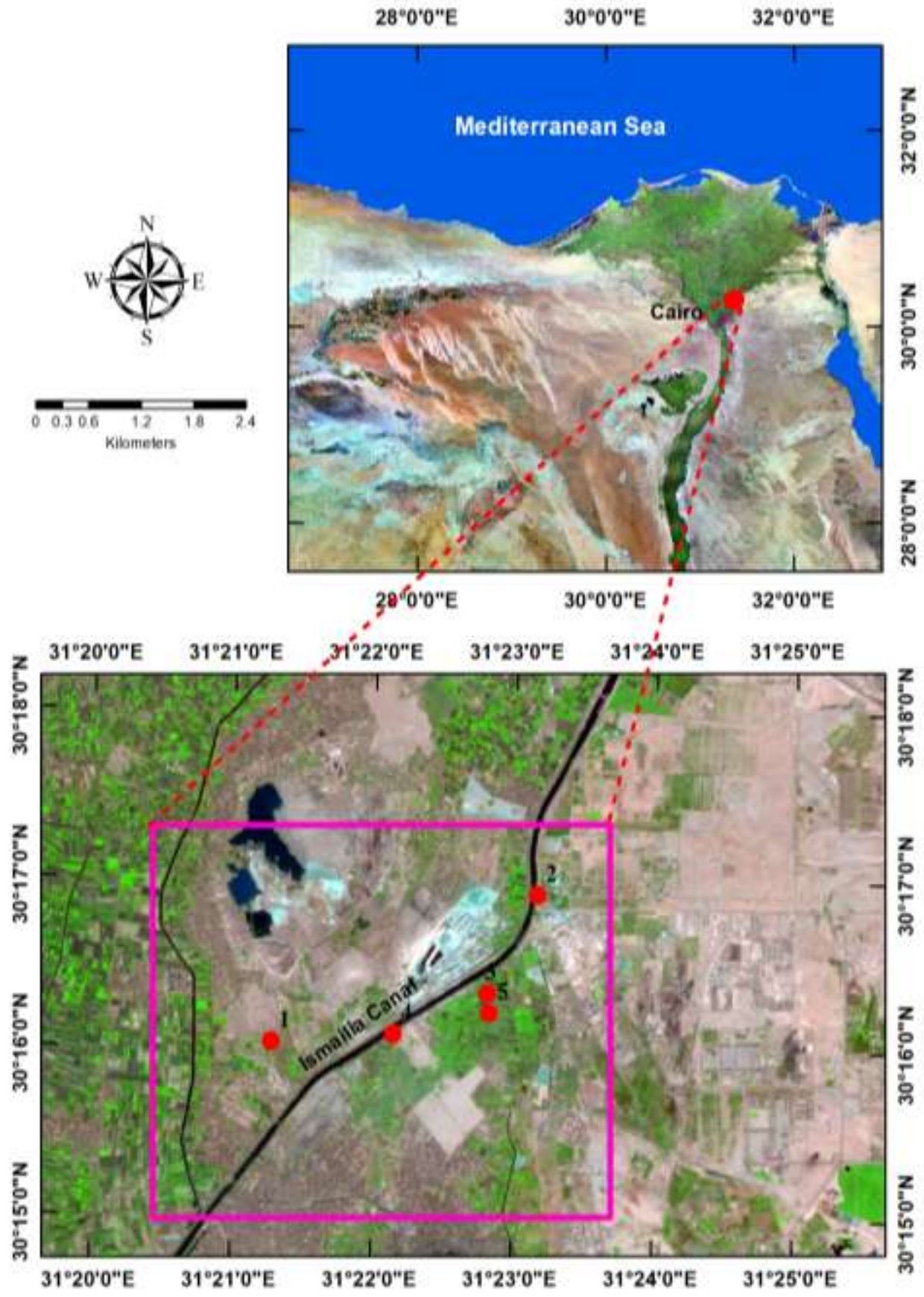

$\square$ study area

Fig (1): Location of the studied soil in Abu-Zaabal area 
The samples were air dried and lumps were broken with a wooden pestle in a wooden mortar so that the soil samples were crushed and through a $2 \mathrm{~mm}$ round hole sieve to discard large pebbles, gravels, rock fragments and pieces of vegetation then quartering is undertaken to get homogenous subsamples for the different analyses. (profile number one its control profile and is located North west of the factory The others profile it is located in South east of the factory).

\section{3/2- Plant sampling.}

Five vegetables plant samples were collected from the plants grown in the study locations and irrigated with Ismailia Canal.

1-Determination of trace metals content in the vegetables plants .

2-Calculation of trace metals accumulation factor and translocation factor.

\section{3/3- Soil samples analyses.}

Textured of the soil samples was determined with the dry sieving method (Piper 1950) .

- $\mathrm{CaCO}_{3}$ content was determined volumetrically using Collin's calcimeter according to Jackson (1973).

- Organic matter content was determined by the method outlined by Jackson (1973).

- Determination of $\mathrm{pH}$ in the soil extract was carried out by Beckman glass electrode $\mathrm{pH}$ - meter, Black (1983).

- Electrical conductivity (EC) of the soil saturation extract as well as soluble anions and cations were determined following the methods described by Jackson (1973). For convenience, $\mathrm{CO}_{3}^{--}, \mathrm{Cl}^{-}, \mathrm{HCO}_{3}{ }^{-}$, were determined titrimetric ally while $\mathrm{SO}_{4}^{--}$was determined gravimetrically by precipitation as barium sulfate. Soluble $\mathrm{Ca}^{++}$and $\mathrm{Mg}^{+}$were determined titrimetric ally using the versenate solution while $\mathrm{Na}^{+}$and $\mathrm{K}^{+}$were determined by flame Photometry, as described by Black (1983).

- Cation exchange capacity (CEC) and exchangeable cations were determined following the methods described by Jackson (1973).

- Total trace metals contents in the soil samples $(\mathrm{Zn}, \mathrm{Cu}, \mathrm{Ni}, \mathrm{Co}, \mathrm{Cr}$ and $\mathrm{Cd}$ ) were determined by the Ionic Coupled Plasma (ICP), after digestion of the samples with a ternary acids mixture of $\mathrm{HNO}_{3}$, $\mathrm{H}_{2} \mathrm{SO}_{4}$ and $\mathrm{HClO}_{4}$, as recommended by Hesse (1971).

- Chemically - extractable amounts of the same elements were extracted from soils by Diethelene triamine pentaacetic acid (DTPA) and determined by Inductively Coupled Plasma, (ICP). Lindsay and Norvell (1978). 


\section{3/4-Plant sampling analysis.}

The vegetables plant samples were thoroughly washed and air dried, then dried in a dryer at $70^{\circ} \mathrm{C}$ for $4 \mathrm{hrs}$. The dried material was then powdered in a hammer mill sample bottles which were used in plant analysis according to requirements. Digested $0.5 \mathrm{~g}$ from the plant powder by $\mathrm{H}_{2} \mathrm{O}_{2}$ and $\mathrm{H}_{2} \mathrm{SO}_{4}$ was used to determine the plant contents of trace metals under study ( $\mathrm{Zn}, \mathrm{Cu}, \mathrm{Ni}, \mathrm{Co}$, and $\mathrm{Cr}$ ) by Ionic Coupled Plasma (ICP)., (Nicholson 1984 )

\section{4/1-Characterization of the studied soils:}

\section{4- RESULTS AND DISSECTION}

From tables $(1 \& 2)$ the soil texture of the studied soil samples is sand (varied from VCS to VFS)to sandy loam. Soil salinity varied from 0.3 to $1.76 \mathrm{ds} / \mathrm{cm}$. Soil reaction Was neutral to alkaline as indicated py $\mathrm{pH}$ values which ranged from 7.28 to 8.02 in the studied soils. Calcium carbonate content ranges from 0.22 to $2.14 \%$. The organic matter percent ranged from 0.35 to $2.89 \%$. The cationic and anionic compositions of the studied soils are generally dominated by $\mathrm{SO}_{4}^{--}>$ $\mathrm{Ca}^{++}>\mathrm{HCO}_{3}{ }^{-}>\mathrm{Mg}^{++}>\mathrm{Na}^{+}>\mathrm{Cl}^{-}>\mathrm{K}^{+}>\mathrm{CO}_{3}{ }^{--}$.CEC for the studied soils ranges from 0.09 to $2.92 \mathrm{me} / 100 \mathrm{~g}$ soil. the narrow range of CEC rendered to lesser extent to silt and clay content in the studied soils.

Table (1) Dry Sieving of the studied soil in Abu - Zaabal area.

\begin{tabular}{|c|c|c|c|c|c|c|c|c|}
\hline Prof. No. & Samp. No. & $\operatorname{Depth}(\mathrm{Cm})$ & VCS \% & CS \% & MS \% & FS \% & VFS \% & SI+CL \% \\
\hline 1-Control & 1 & $0-25$ & 13.29 & 31.08 & 37.78 & 12.15 & 1.93 & 3.77 \\
\hline $\begin{array}{lllll}0^{\circ} & 16^{\prime} & 02^{\prime \prime} & \mathrm{N}\end{array}$ & 2 & $25-50$ & 4.60 & 21.43 & $\mathbf{5 3 . 5 2}$ & 13.70 & 1.80 & 4.95 \\
\hline & 3 & $50-75$ & 10.74 & 35.51 & 35.15 & 4.69 & 0.36 & 19.55 \\
\hline $31^{\circ} 21^{\prime} 17^{/ /} \mathbf{E}$ & 4 & $75-100$ & 10.01 & 33.71 & 48.66 & 6.82 & 0.40 & 0.40 \\
\hline 2 & 5 & $0-40$ & 8.32 & 36.29 & 38.63 & 11.67 & 1.97 & 3.23 \\
\hline $30^{\circ} \mathbf{1 6}^{\prime} \mathbf{5 5}^{\prime \prime} \mathrm{N}$ & 6 & $40-70$ & 8.21 & 28.11 & 44.61 & 13.12 & 1.95 & 4.00 \\
\hline & 7 & $70-100$ & 11.74 & 25.00 & 42.66 & 13.80 & 1.57 & 5.00 \\
\hline $31^{\circ} 23^{\prime} 10^{\prime \prime} \mathrm{E}$ & 8 & $100--120$ & 19.00 & 31.62 & 40.82 & $\mathbf{7 . 7 0}$ & 0.43 & 0.96 \\
\hline 3 & 9 & 0 - 30 & 8.95 & 30.38 & 30.52 & 10.13 & 3.15 & 18.77 \\
\hline $\begin{array}{llll}30^{\circ} & 16^{\prime} & 20^{1 /} \mathrm{N} \\
\end{array}$ & 10 & $30-60$ & 10.49 & 28.73 & 30.27 & 11.71 & 2.32 & 17.38 \\
\hline & 11 & $60-90$ & 7.53 & 46.27 & 34.87 & 5.94 & 1.31 & 4.09 \\
\hline $31^{\circ} 22^{\prime} 49^{\prime /} \mathrm{E}$ & 12 & $90-150$ & 15.82 & 30.92 & 37.16 & 11.51 & 0.21 & 4.26 \\
\hline 4 & 13 & $0-30$ & 2.77 & 20.24 & 35.56 & 14.88 & 2.59 & 22.95 \\
\hline $\begin{array}{llll}30^{\circ} & 16^{\prime} & 05^{\prime \prime} & \mathrm{N} \\
\end{array}$ & 14 & $30-55$ & 9.65 & 24.45 & 48.85 & 11.75 & 2.60 & 2.20 \\
\hline & 15 & $55-80$ & 4.10 & 32.07 & 55.41 & 7.15 & 0.63 & 0.64 \\
\hline $31^{\circ} 22^{\prime} 90^{\prime /} \mathrm{E}$ & 16 & $80-120$ & 2.21 & 19.52 & 67.99 & 9.70 & 0.37 & 0.21 \\
\hline 5 & 17 & $00-30$ & 8.99 & 27.91 & 37.36 & 16.11 & 4.07 & 5.56 \\
\hline $\begin{array}{llll}3^{\circ} & 16^{\prime} & 13^{\prime / /} \mathrm{N} \\
\end{array}$ & 18 & $30-50$ & 8.54 & 21.55 & 44.56 & 17.59 & 42.83 & 2.90 \\
\hline & 19 & $50-80$ & 13.39 & 25.70 & 38.34 & 14.53 & 3.54 & 4.50 \\
\hline $31^{\circ} 22^{\prime} 50^{\prime \prime} \mathrm{E}$ & 20 & $80-100$ & 6.62 & 22.24 & 30.51 & 15.64 & 4.33 & 20.66 \\
\hline
\end{tabular}

*VCS : Very Coarse Sand.

*CS : Coarse Sand.

MS: Medium Sand.

*VFS : Very Fine Sand.

FS: Fine Sand

$\mathrm{Si}+\mathrm{Cl}:$ Silt +Cla 
Table (2) Chemical properties of the studied soils.

\begin{tabular}{|c|c|c|c|c|c|c|c|c|c|c|c|c|c|c|c|}
\hline \multirow{2}{*}{$\begin{array}{l}\text { Prof. } \\
\text { NO. }\end{array}$} & \multirow{2}{*}{$\begin{array}{c}\text { Samp. } \\
\text { No. }\end{array}$} & \multirow{2}{*}{$\begin{array}{c}\text { Depth } \\
(\mathrm{cm}) \\
\end{array}$} & \multirow{2}{*}{$\mathbf{p H}$} & \multirow{2}{*}{$\begin{array}{c}E C \\
d s / m\end{array}$} & \multirow{2}{*}{$\frac{\mathrm{CaCO}_{3}}{\%}$} & \multirow{2}{*}{$\begin{array}{c}\text { O.M } \\
\% \\
\end{array}$} & \multicolumn{4}{|c|}{ Cations (Me/l ) } & \multicolumn{4}{|c|}{ Anions (me/L ) } & \multirow{2}{*}{ CECMe/100g } \\
\hline & & & & & & & $\mathbf{N a}^{+}$ & $\mathbf{K}^{+}$ & $\mathbf{C a}^{++}$ & $\mathrm{Mg}++$ & $\mathrm{CO}_{3}^{--}$ & $\mathrm{HCO}_{3}^{-}$ & $\mathrm{Cl}^{-}$ & $\mathrm{SO}_{4}^{--}$ & \\
\hline \multirow{4}{*}{ 1-Control } & 1 & 0 - 25 & 7.56 & 0.68 & 2.00 & 2.66 & 1.1 & 0.3 & 3.00 & 2.40 & 0.00 & 4.20 & 0.70 & 1.94 & 0.09 \\
\hline & 2 & $25-50$ & 7.59 & 0.35 & 0.65 & 1.38 & 0.7 & 0.3 & 1.80 & 1.40 & 0.00 & 2.60 & 0.80 & 0.76 & 2.07 \\
\hline & 3 & $50-75$ & 8.02 & 0.50 & 0.33 & 1.04 & 0.5 & 0.2 & 1.80 & 2.00 & 0.00 & 2.20 & 0.60 & 1.76 & 1.15 \\
\hline & 4 & $75-100$ & 7.61 & 0.30 & 0.33 & 0.75 & 0.5 & 0.2 & 1.60 & 0.80 & 0.00 & 1.00 & 0.50 & 1.56 & 2.31 \\
\hline \multirow{4}{*}{2} & 5 & 0 - 40 & 7.56 & 0.49 & 0.43 & 2.89 & 0.7 & 0.2 & 2.40 & 1.60 & 0.00 & 2.60 & 0.90 & 1.40 & 1.64 \\
\hline & 6 & $40-70$ & 7.57 & 0.38 & $\mathbf{0 . 3 3}$ & 1.51 & 0.5 & 0.1 & 1.60 & 1.60 & 0.00 & 2.20 & 0.70 & 0.01 & 2.26 \\
\hline & 7 & $70-100$ & 7.83 & 0.37 & 0.22 & 0.92 & 0.3 & 0.1 & 2.20 & 1.40 & 0.00 & 2.10 & 0.60 & 1.20 & 1.10 \\
\hline & 8 & 100- -120 & 7.63 & 0.51 & 0.22 & 0.35 & 0.4 & 0.1 & 2.60 & 2.00 & 0.00 & 2.00 & 1.00 & 1.50 & 1.89 \\
\hline \multirow{4}{*}{3} & 9 & 0 - 30 & 7.28 & 1.78 & 1.37 & 1.37 & 1.00 & 0.3 & 13.20 & 3.20 & 0.00 & 2.00 & 1.00 & 14.68 & 1.52 \\
\hline & 10 & $30-60$ & 7.46 & 0.46 & 2.14 & 2.14 & 0.6 & 0.2 & 2.80 & 2.20 & 0.00 & 2.80 & 0.60 & 2.32 & 2.57 \\
\hline & 11 & $60-90$ & 7.43 & 0.37 & 1.39 & 1.39 & 0.3 & 0.1 & 2.40 & 1.40 & 0.00 & 2.60 & 0.80 & 1.00 & 1.53 \\
\hline & 12 & $90-150$ & 7.57 & 0.47 & 0.69 & 0.69 & 0.4 & 0.1 & 3.60 & 0.60 & 0.00 & 3.00 & 0.60 & 1.00 & 2.88 \\
\hline \multirow{4}{*}{4} & 13 & 0 -30 & 7.35 & 0.49 & 0.75 & 1.44 & 0.6 & 0.2 & 3.20 & 1.20 & 0.00 & 3.60 & 0.50 & 1.11 & 2.92 \\
\hline & 14 & $30-55$ & 7.73 & 0.49 & 0.65 & 1.32 & 0.7 & 0.2 & 3.60 & 1.00 & 0.00 & 3.20 & 0.40 & 1.85 & 1.69 \\
\hline & 15 & $55-80$ & 7.47 & 0.33 & 0.43 & 0.98 & 0.4 & 0.1 & 0.60 & 1.00 & 0.00 & 2.40 & 0.60 & 0.16 & 2.12 \\
\hline & 16 & 80 - 120 & 7.73 & 0.31 & 0.43 & 0.41 & 0.3 & 0.1 & 1.20 & 1.60 & 0.00 & 1.20 & 0.50 & 1.47 & 1.58 \\
\hline \multirow{4}{*}{5} & 17 & 00 - 30 & 7.69 & 0.45 & 0.87 & 1.33 & 0.4 & 0.1 & 3.00 & 1.40 & 0.00 & 3.20 & 0.60 & 1.11 & 3.03 \\
\hline & 18 & $30-50$ & 7.71 & 0.45 & 1.3 & 0.92 & 0.3 & 0.1 & 2.20 & 1.80 & 0.00 & 2.40 & 0.50 & 1.56 & 2.64 \\
\hline & 19 & $50-80$ & 7.69 & 0.53 & 0.87 & 0.87 & 0.6 & 0.1 & 2.60 & 1.80 & 0.00 & 2.60 & 0.50 & 2.04 & 1.39 \\
\hline & 20 & $80-100$ & 7.46 & 0.60 & 0.87 & 0.81 & 0.2 & 0.10 & 2.40 & 1.80 & 0.00 & 3.00 & 0.40 & 2.64 & 2.63 \\
\hline
\end{tabular}




\section{4/2- Trace metals:}

The current study include five trace metals which are mostly of high density (heavy metals).Some of these have been termed trace elements or micronutrients in agriculture, stressing their relatively low abundance in regular soils and the fact that they tend to be essential for plant growth $(\mathrm{Zn} \& \mathrm{Cu})$. Other trace metals presumably sometimes involved in pollution problems are also included ( $\mathrm{Ni} \& \mathrm{Cr}$ ). With regard to toxicology, some commonly accepted toxic effects on human beings, animals and plants. the five trace metals considered here are $\mathrm{Zn}, \mathrm{Cu}, \mathrm{Ni}$, $\mathrm{Co}$ and $\mathrm{Cr}$. Among these $\mathrm{Zn}, \mathrm{Cu}, \mathrm{Ni}$, and $\mathrm{Co}$ are present in small amounts in biological tissue and have been shown to be essential for the healthy development of the plant or animal concerned while $\mathrm{Cr}$ occur in biological materials, although their essentiality has not been established and hazardous above certain low levels. In short, trace metals in soils can refer either to the biological significance of such metals to plants and animals (Elwa.2016).

\section{4/2/1-Total trace metals in soils:}

Data in table (3) involved the total content of trace metals in the studied soil samples total Cr content varied from $15.74 \mathrm{mg} / \mathrm{kg}$ in deposit layer in the profile 1 to $118.90 \mathrm{mg} / \mathrm{kg}$ in the surface layer in the profile 3.the value above the permissible limits its sure to move from soil to plants and then enter to the food chain. Polluting her. total $\mathrm{Cu}$ the least value of $1.67 \mathrm{mg} / \mathrm{kg}$ which found in the deposit layer in the profile 1.while the highest value $91.32 \mathrm{mg} / \mathrm{kg}$ in the surface layer in the profile 3 . This value getting close to contamination limits over time the copper element will accumulate in soil and transfer to plants causing toxicity. Total Ni ranges from $2.68 \mathrm{mg} / \mathrm{kg}$ in deposit layer in the profile 4 . where's the highest value $39.51 \mathrm{mg} / \mathrm{kg}$ which found in the sub surface layer in the profile 3 in the studied soils. So the studied area quite far from nickel contamination. Total $\mathrm{Zn}$ ranges from $11.83 \mathrm{mg} / \mathrm{kg}$ in the deposit layer in the profile 4 . but the highest value $67.95 \mathrm{mg} / \mathrm{kg}$ which present in the surface layer in the profile 2.Total Co varied form 1.15 $\mathrm{mg} / \mathrm{kg}$ which found in the sub surface layer in the profile 1.wheres the highest value $26.08 \mathrm{mg} / \mathrm{kg}$ which present in the subsurface layer in the profile 2 in the studied soils. in this respect, the Maximum permissible concentrations of heavy metals in agricultural soils reported by (Kabata-Pendias and Pendias 2001) are: $\mathrm{Cd}$ (cadmium) 5 $\mathrm{mg} / \mathrm{kg}$, Co (cobalt) $50 \mathrm{mg} / \mathrm{kg}, \mathrm{Cr}$ (chromium) $100 \mathrm{mg} / \mathrm{kg}, \mathrm{Cu}$ (copper) $100 \mathrm{mg} / \mathrm{kg}$, Ni (nickel) $100 \mathrm{mg} / \mathrm{kg}$, Pb (lead) $100 \mathrm{mg} / \mathrm{kg}$, and Zn (zinc) $300 \mathrm{mg} / \mathrm{kg}$.So the total concentration of trace metals in the studied soils in Abu -Zaabal area in table (3) below the permissible limits except chromium $\mathrm{Cr}$ in the surface layer $(0-30 \mathrm{~cm})$ in the profile 3 the total concentration $118.90 \mathrm{mg} / \mathrm{dl}$. Also the total content of trace metals in 
profile one ( Control profile) is lesser than the total content in the others profiles with some exceptions.

Table (3) Total trace metals in the studied soils

\begin{tabular}{|c|c|c|c|c|c|c|c|}
\hline profi. & Samp. & Depth & Total $\mathrm{Cr}$ & Total Cu & Total Ni & Total Zn & Total Co \\
\hline No. & No. & $(\mathrm{cm})$ & $\mathrm{mg} / \mathrm{kg}$ & $\mathrm{mg} / \mathrm{kg}$ & $\mathrm{mg} / \mathrm{kg}$ & $\mathrm{mg} / \mathrm{kg}$ & $\mathrm{mg} / \mathrm{kg}$ \\
\hline \multirow{4}{*}{ 1-Control } & 1 & $0-25$ & 30.91 & 16.40 & 15.65 & 59.46 & 7.34 \\
\hline & 2 & $25-50$ & 36.63 & 15.57 & 20.68 & 48.39 & 1.15 \\
\hline & 3 & $50-75$ & 15.74 & 2.00 & 10.07 & 35.70 & 3.00 \\
\hline & 4 & $75-100$ & 19.63 & 1.67 & 14.82 & 14.82 & 1.94 \\
\hline \multirow{4}{*}{2} & 5 & $0-40$ & 59.37 & 30.03 & 20.68 & 67.95 & 13.91 \\
\hline & 6 & $40-70$ & 49.40 & 23.06 & 20.47 & 45.96 & 17.48 \\
\hline & 7 & $70-100$ & 41.40 & 13.67 & 19.56 & 41.84 & 6.87 \\
\hline & 8 & $100--120$ & 31.34 & 6.55 & 6.51 & 24.19 & 5.98 \\
\hline \multirow{4}{*}{3} & 9 & $0-30$ & 118.90 & 91.32 & 29.75 & 24.19 & 20.31 \\
\hline & 10 & $30-60$ & 97.30 & 87.71 & 39.51 & 20.32 & 26.08 \\
\hline & 11 & $60-90$ & 32.12 & 8.21 & 12.58 & 16.40 & 5.93 \\
\hline & 12 & $90-150$ & 22.16 & 8.79 & 2.70 & 23.90 & 4.88 \\
\hline \multirow{4}{*}{4} & 13 & $0-30$ & 17.42 & 8.34 & 10.70 & 15.79 & 8.92 \\
\hline & 14 & $30-55$ & 30.14 & 15.17 & 5.26 & 25.10 & 6.61 \\
\hline & 15 & $55-80$ & 28.22 & 9.47 & 6.03 & 21.90 & 7.45 \\
\hline & 16 & $80-120$ & 17.81 & 2.94 & 2.68 & 11.83 & 5.46 \\
\hline \multirow{5}{*}{5} & 17 & 0 - 30 & 29.22 & 16.74 & 12.68 & 36.29 & 9.50 \\
\hline & 18 & $30-50$ & 35.15 & 14.67 & 12.24 & 39.55 & 6.61 \\
\hline & 19 & $50-80$ & 56.80 & 37.08 & 28.14 & 66.16 & 14.64 \\
\hline & 20 & $80-100$ & 41.71 & 13.21 & 8.12 & 26.01 & 5.25 \\
\hline & P.L.T.M & $\mathrm{Mg} / \mathrm{kg}$ & 100.0 & 100.0 & 100.0 & 300.0 & $\begin{array}{l}50.0 \\
\end{array}$ \\
\hline
\end{tabular}

P.L.T.M = Permissible limits of total trace metals.

\section{4/2/2-Chemically extractable}

Data in table (4) include chemically extractable of trace metals in the studied soils.

Chemically extractable of $\mathrm{Cu}$ ranges from $0.56 \mathrm{mg} / \mathrm{kg}$ in the deposit layer $(75-100 \mathrm{~cm})$ in the profile 1 to $15.64 \mathrm{mg} / \mathrm{kg}$ in the surface layer $(0-30 \mathrm{~cm})$ of the profile 3 of studied soils.

Chemically extractable of $\mathrm{Zn}$ varied from $2.99 \mathrm{mg} / \mathrm{kg}$ in the deposit layer $(80-120 \mathrm{~cm}$ ) in the profile 4 to $12.40 \mathrm{mg} / \mathrm{kg}$ in deposit layer of the profile 4 .

The value of chemically extractable Co ranges from $0.50 \mathrm{mg} / \mathrm{kg}$ to $5.22 \mathrm{mg} / \mathrm{kg}$ in the studied soils.

Chemically extractable of $\mathrm{Ni}$ in the studied soils ranges from 1.06 $\mathrm{mg} / \mathrm{kg}$ to $8.26 \mathrm{mg} / \mathrm{kg}$. The value of chemically extractable Cr ranges from $3.25 \mathrm{mg} / \mathrm{kg}$ to $20.34 \mathrm{mg} / \mathrm{kg}$. The maximum permissible concentrations of extractable of trace metals in soil are the following,: $\mathrm{Pb}-6,0 \mathrm{mg} / \mathrm{kg}$ and $\mathrm{Cr}-6,0 \mathrm{mg} / \mathrm{kg} \mathrm{Ni}-4,0 \mathrm{mg} / \mathrm{kg} \mathrm{Co}-5.0 \mathrm{mg} / \mathrm{kg} \mathrm{Zn}-23,0 \mathrm{mg} / \mathrm{kg} \mathrm{Cu}-3,0$ $\mathrm{mg} / \mathrm{kg}$ (Kabata-Pendias and Pendias 2001).

So the chemically extractable of trace metals in the studied soils in Abu -Zabaal area above the permissible level this due to the waste of 
Abu Zaabal fertilizers factories in this region , Irrigation water from Ismailia canal and agrochemicals ( fertilizers ,pesticides) as mentioned (Bhatt et al., 2016 ) .

By view to data in table (4) chemically extractable of all trace metals in all profiles above the permissible level except cobalt ( $\mathrm{Co}$ ) in all profile below the permissible level but subsurface layer $(30-60 \mathrm{~cm})$ in the profile 3 the chemically extractable of Co equal $5.22 \mathrm{mg} / \mathrm{kg}$.So all the trace metals in the studied soils in Abu -Zaable area become polluting and hazardous to animals and human by transfer from soil to plants and enter to the food chain. chemically extractable of all trace metals in the profile one(Control profile ) is lesser than chemically extractable of all trace metals in the others profiles.

Table 4) chemically extractable of trace metals in the studied soils.

\begin{tabular}{|c|c|c|c|c|c|c|c|}
\hline Prof. & Sampl. & Depth & $\mathrm{Cu}$ & $\mathbf{Z n}$ & Co & $\mathrm{Ni}$ & $\mathrm{Cr}$ \\
\hline No. & No. & $(\mathbf{C m})$ & $\mathrm{Mg} / \mathrm{kg}$ & $(\mathrm{mg} / \mathrm{kg})$ & $(\mathrm{mg} / \mathrm{kg})$ & $(\mathrm{mg} / \mathrm{kg})$ & $(\mathrm{mg} / \mathrm{kg})$ \\
\hline \multirow{4}{*}{ 1- Control } & 1 & $0-25$ & 4.12 & 8.64 & 2.31 & 3.36 & 7.32 \\
\hline & 2 & $25-50$ & 3.50 & 7.36 & 0.50 & 4.58 & 8.21 \\
\hline & 3 & $50-75$ & 0.76 & 5.47 & 0.90 & 2.40 & 3.25 \\
\hline & 4 & $75-100$ & 0.56 & 3.60 & 0.88 & 3.20 & 4.65 \\
\hline \multirow{4}{*}{2} & 5 & $0-40$ & 7.24 & 9.29 & 3.20 & 5.12 & 10.21 \\
\hline & 6 & $40-70$ & 5.90 & 7.26 & 4.24 & 4.92 & 9.20 \\
\hline & 7 & $70-100$ & 3.26 & 6.33 & 2.00 & 3.80 & 8.26 \\
\hline & 8 & $100--120$ & 1.89 & 5.28 & 1.98 & 2.03 & 7.21 \\
\hline \multirow{4}{*}{3} & 9 & 0 - 30 & 10.64 & 7.14 & 4.11 & 7.25 & 20.34 \\
\hline & 10 & $30-60$ & 13.46 & 6.10 & 5.22 & 8.26 & 15.46 \\
\hline & 11 & $60-90$ & 2.01 & 4.26 & 1.99 & 3.33 & 7.22 \\
\hline & 12 & $90-150$ & 2.04 & 5.20 & 1.05 & 1.06 & 4.20 \\
\hline \multirow{4}{*}{4} & 13 & 0 -30 & 2.01 & 5.28 & 2.01 & 2.85 & 4.20 \\
\hline & 14 & $30-55$ & 3.99 & 6.87 & 2.13 & 1.32 & 6.25 \\
\hline & 15 & $55-80$ & 3.26 & 4.29 & 2.65 & 2.01 & 7.30 \\
\hline & 16 & 80 - 120 & 0.90 & 2.99 & 1.89 & 1.69 & 3.99 \\
\hline \multirow{4}{*}{5} & 17 & 0 - 30 & 4.35 & 8.20 & 3.22 & 3.26 & 7.22 \\
\hline & 18 & $30-50$ & 3.87 & 8.30 & 2.11 & 3.09 & 8.12 \\
\hline & 19 & $50-80$ & 7.22 & 12.40 & 3.50 & 6.55 & 8.56 \\
\hline & 20 & $80-100$ & 3.87 & 4.85 & 1.28 & 2.03 & 7.16 \\
\hline P.L.E.T.M & $\mathrm{Mg} / \mathrm{kg}$ & & 3.0 & 23.0 & 5.0 & 4.0 & 6.0 \\
\hline
\end{tabular}

\section{4/3-Heavy metals in grown plants}

\section{Copper in grown plants}

Data in table (5) $\mathrm{Cu}$ content in vegetables grown in the studied area above the permissible limits except taro vegetable which grown in the profiles 2 .but $(\mathrm{Zn})$ and $(\mathrm{Cr})$ concentration in all profiles is higher than the contamination level leads to transfer this polluting to human and animals across the food chain leads to hazardous problems healthy. 
Table (5): Total trace metals in the plants grown in the studied area.

\begin{tabular}{|c|c|c|c|c|c|c|}
\hline Prof.No. & & Cu & Zn & Co & Ni & Cr \\
\hline 1 & Types of plant & \multicolumn{5}{|c|}{$(\mathbf{m g} / \mathbf{k g})$} \\
Control & Potatoes fruit & 15.90 & $\mathbf{2 0 . 5 8}$ & 1.1 & $\mathbf{9 . 3 2}$ & $\mathbf{8 . 2 9}$ \\
\hline 2 & Taro fruit & $\mathbf{9 . 1 3}$ & $\mathbf{3 6 . 1 6}$ & $\mathbf{1 . 2 6}$ & $\mathbf{3 . 6 8}$ & $\mathbf{9 . 1 3}$ \\
\hline 3 & Egg plant & $\mathbf{2 2 . 4 9}$ & $\mathbf{4 1 . 3 3}$ & $\mathbf{0 . 4 2}$ & $\mathbf{8 . 7 3}$ & $\mathbf{3 5 . 1 8}$ \\
\hline 4 & The Faba bean & $\mathbf{4 3 . 7 8}$ & $\mathbf{4 0 . 2 4}$ & $\mathbf{0 . 2 4}$ & $\mathbf{9 . 0 2}$ & $\mathbf{2 4 . 4 6}$ \\
\hline 5 & Onion plant & $\mathbf{2 3 . 1 8}$ & $\mathbf{5 4 . 2 0}$ & $\mathbf{1 . 2 1}$ & $\mathbf{4 . 9 3}$ & $\mathbf{3 3 . 2 4}$ \\
\hline Permissible limits & Mg/kg & 10.0 & $\mathbf{5 . 0}$ & $\mathbf{5 0 . 0}$ & $\mathbf{1 0 . 0}$ & $\mathbf{1 . 3}$ \\
\hline
\end{tabular}

Total trace metals in the plants which grown in the studied soils:

$\mathrm{Cu}, \mathrm{Zn}$ and Ni are essential micronutrients .( Ashok et al, 2010).( Guan et al ,2011) (Wahla and Kirkham ,2008).but $\mathrm{Cr}$ and $\mathrm{Co}$ not essential to plants but are useful to human and animals .The mean need of 50 - 200 micr.g/day from chromium. WHO.(2011).Okamoto et al .(1978) theirs not essential role for Co in plants has not been demonstrated. From data in table (6) the cobalt (Co ) and Nickel ( Ni ) levels analyzed were below permissible limit set by FAO/WHO, $2001(50.00$ $\mathrm{mg} / \mathrm{Kg}$ )and $10.0 \mathrm{mg} / \mathrm{kg}$ for ( $\mathrm{Ni}$ ) there by these vegetables are free of its contamination in the studied soils. Asaolu, S.S., 1995 reported the permissible limits of some trace metals in edible portion of vegetables as the follow $\mathrm{Ni} 10.0 \mathrm{mg} / \mathrm{kg}, \mathrm{Cr}$ $1.3 \mathrm{mg} / \mathrm{kg}, \mathrm{Zn} \mathrm{5.0mg/kg}$ and $\mathrm{Cu} 10.0 \mathrm{mg} / \mathrm{kg}$.

\section{4/4- Translocation factor (TF) .}

Translocation factor ( $\mathrm{TF}$ ) : transfer the metals from roots or soil to shoot (Ma, et al 2001)

$\mathrm{TF}=$ metal in shoot /metal in soil or $($ root $)$

4/5- Biological accumulation Factor (BAF) :

Determine the ability of the plant to uptake the metal from the soil . BAF $($ shoot $)=$ metal in shoot $/$ metal in soil .

Data in table (6) represent the translocation factor and biological accumulation factor of $(\mathrm{Cu})$ metal in the vegetables' which grown in the studied soil .we find ( TF ) in all vegetables in all profiles $>1$ and ( BAF ) $>1$ this means occur transfer and accumulate high percent of Copper metal from contaminated soil to vegetables' which considered as a hyper accumulators (Blalyock and Huang (2005). Variation of metal translocation and uptake due to different concentration of metal in soil , organic matter , PH ,in soil, age of plant as mentioned (Khan, et al 2015).

Table (6) Translocation factor (TF ) \&Biological accumulation factor of $\mathrm{Cu}$

\begin{tabular}{|c|c|c|c|c|c|c|}
\hline Land use & Prof.No. & $\begin{array}{c}\text { Type of } \\
\text { plants }\end{array}$ & Cu in soil & Cu in plant & T.F & BAC \\
\hline $\begin{array}{c}\text { Cultivated soil } \\
\text { (Control) }\end{array}$ & 1 & Potatoes fruit & 4.12 & 15.90 & 3.86 & 3.86 \\
\hline Cultivated soil & 2 & Taro fruit & 7.24 & 9.13 & 1.26 & 1.26 \\
\hline Cultivated soil & 3 & Egg plant & 10.64 & 22.49 & 2.11 & 2.11 \\
\hline Cultivated soil & 4 & Fabe bean & 2.01 & 43.78 & 21.78 & 21.78 \\
\hline Cultivated soil & 5 & Onion plan & 4.35 & 23.18 & 5.33 & 5.33 \\
\hline
\end{tabular}

TF : metals in vegetables /metals in soil

BAF : metal in vegetables /metals in soil 


\section{4/6- Zinc in grown plant}

Data in table (7) explain translocation factor and biological accumulation factor for $(\mathrm{Zn})$.We find $(\mathrm{TF})$ and $(\mathrm{BAF})$ in profile 1.where potatoes fruit is grown is very low than other profiles as TF \& BAF in potatoes $<$ Taro fruit $<<$ Egg plant $<$ Onion plant $<$ Faba bean . but all the vegetables as hyper accumulators with different proportions by toxic Zinc. Although metals such as zinc, copper and manganese are essential trace elements for plants and animals, they can also be dangerous at high exposure levels. For example, poisoning incidents with symptoms of gastrointestinal distress, nausea and diarrhea have been reported after a single or short-term exposure to concentrations of zinc in water (WHO 2001). At high doses of certain metal compounds, of the order of several grams, chronic toxicity or carcinogenicity as well as fatality may occur.

Table (7): Translocation factor (TF ) \&Biological accumulation factor of $\mathbf{Z n}$

\begin{tabular}{|c|c|c|c|c|c|c|}
\hline Land use & Prof.No. & $\begin{array}{c}\text { Type of } \\
\text { Plants }\end{array}$ & $\begin{array}{c}\text { Zn in soil } \\
\text { Mg/kg }\end{array}$ & $\begin{array}{c}\text { Zn in plant } \\
\mathrm{mg} / \mathrm{kg}\end{array}$ & $\begin{array}{c}\text { T.F } \\
\mathrm{mg} / \mathrm{kg}\end{array}$ & $\begin{array}{c}\text { BAF } \\
\mathrm{mg} / \mathrm{kg}\end{array}$ \\
\hline $\begin{array}{c}\text { Cultivated soil } \\
\text { ( Control) }\end{array}$ & 1 & $\begin{array}{c}\text { Potatoes } \\
\text { fruit }\end{array}$ & $\mathbf{8 . 6 4}$ & $\mathbf{2 0 . 5 8}$ & 2.38 & 2.38 \\
\hline Cultivated soil & $\mathbf{2}$ & Taro fruit & $\mathbf{9 . 2 9}$ & $\mathbf{3 6 . 1 6}$ & $\mathbf{3 . 8 9}$ & $\mathbf{3 . 8 9}$ \\
\hline Cultivated soil & $\mathbf{3}$ & Egg plant & $\mathbf{7 . 1 4}$ & $\mathbf{4 1 . 3 3}$ & $\mathbf{5 . 7 9}$ & $\mathbf{5 . 7 9}$ \\
\hline Cultivated soil & $\mathbf{4}$ & Faba bean & $\mathbf{5 . 2 8}$ & $\mathbf{4 0 . 2 4}$ & $\mathbf{7 . 6 2}$ & $\mathbf{7 . 6 2}$ \\
\hline Cultivated soil & $\mathbf{5}$ & Onion plant & $\mathbf{8 . 2 0}$ & $\mathbf{5 4 . 2 0}$ & $\mathbf{6 . 6 1}$ & $\mathbf{6 . 6 1}$ \\
\hline
\end{tabular}

\section{4/7- Cobalt in grown plants}

Data in table (8) TF and BAF in all vegetables which grown in profile $<1$ This means all vegetables are free contamination in the studied soils by Cobalt metal

Table (8): Translocation factor (TF) \& Biological accumulation factor (BAF) of Co

\begin{tabular}{|c|c|c|c|c|c|c|}
\hline Land use & Prof.No. & Type of plant & $\begin{array}{c}\text { Co in soil } \\
\text { Mg/kg }\end{array}$ & $\begin{array}{c}\text { Co in } \\
\text { plant } \\
\text { mg/kg }\end{array}$ & $\begin{array}{c}\text { T.F } \\
\mathrm{mg} / \mathrm{kg}\end{array}$ & $\begin{array}{c}\text { BAC } \\
\mathrm{mg} / \mathrm{kg}\end{array}$ \\
\hline $\begin{array}{c}\text { Cultivated soil } \\
\text { Control }\end{array}$ & 1 & Potatoes fruit & 2.31 & 1.80 & $\mathbf{0 . 7 8}$ & $\mathbf{0 . 7 8}$ \\
\hline Cultivated soil & 2 & Taro fruit & $\mathbf{3 . 2 0}$ & 1.26 & $\mathbf{0 . 3 9}$ & $\mathbf{0 . 3 9}$ \\
\hline Cultivated soil & $\mathbf{3}$ & Egg plant & $\mathbf{4 . 1 1}$ & $\mathbf{0 . 4 2}$ & $\mathbf{0 . 1 0}$ & $\mathbf{0 . 1 0}$ \\
\hline Cultivated soil & 4 & Faba bean & $\mathbf{2 . 0 1}$ & $\mathbf{0 . 2 4}$ & $\mathbf{0 . 1 2}$ & $\mathbf{0 . 1 2}$ \\
\hline Cultivated soil & $\mathbf{5}$ & Onion plant & $\mathbf{3 . 2 2}$ & $\mathbf{1 . 2 1}$ & $\mathbf{0 . 3 6}$ & $\mathbf{0 . 3 6}$ \\
\hline
\end{tabular}

\section{4/8- Nickel in grown plants.}

Data presented in table (9) show the TF \&BAF in all vegetables > 1 in profiles $2,3,4,5$ moderate contamination in the studied soils but in profile 1 its high contamination by Nickal metal. 
Table (9): Translocation factor (TF) \& Biological accumulation factor (BAF) of $\mathrm{Ni}$

\begin{tabular}{|l|l|l|l|l|l|l|}
\hline Land use & Prof.No. & Type of plant & Ni in soil & Ni in plant & T.F & BAF \\
\hline & & & Mg/kg & $\mathrm{mg} / \mathrm{kg}$ & $\mathrm{mg} / \mathrm{kg}$ & $\mathrm{mg} / \mathrm{kg}$ \\
\hline $\begin{array}{l}\text { Cultivated soil } \\
\text { Control }\end{array}$ & $\mathbf{1}$ & $\begin{array}{l}\text { Potatoes } \\
\text { fruit }\end{array}$ & 3.36 & 9.32 & 2.77 & 2.77 \\
\hline Cultivated soil & 2 & Taro fruit & 3.20 & 3.68 & 1.15 & 1.15 \\
\hline Cultivated soil & 3 & Egg plant & 7.25 & 8.73 & 1.20 & 1.20 \\
\hline Cultivated soil & 4 & Faba bean & $\mathbf{2 . 8 5}$ & $\mathbf{9 . 0 2}$ & 1.16 & 1.16 \\
\hline Cultivated soil & 5 & Onion plant & 3.26 & 4.93 & 1.51 & 1.51 \\
\hline
\end{tabular}

\section{4/9- Chromium in grown plants}

Data in table (10) show the translocation factor and biological accumulation factor in profiles $1,3,4,5>1$.So all vegetables in ranges between moderate and high contaminated by $\mathrm{Cr}$ metals But in profile 1 the translocation factor and biological accumulation factor $<1$. So the vegetables in this profile in the studied soils considered as low contaminated by $\mathrm{Cr}$. hyper accumulator for Chromium metal due to are had ability to transfer the metal from contaminated soil and take up to the plant. respectively Faba bean > Onion plant > Potatoes fruit > Egg plant $>$ Taro fruit. this vegetables become toxic by $(\mathrm{Cr})$ when reached to the food chain.

Table (10) Translocation factor ( TF) \& Biological accumulation factor ( BAF ) of $\mathrm{Cr}$

\begin{tabular}{|l|l|l|l|l|l|l|}
\hline Land use & Prof.No. & Type of plant & $\begin{array}{l}\text { Cr in } \\
\text { soil }\end{array}$ & $\begin{array}{l}\text { Cr in } \\
\text { plant }\end{array}$ & T.F & BAF \\
\hline $\begin{array}{l}\text { Cultivated soil } \\
\text { Control }\end{array}$ & & & Mg/kg & mg/kg & mg/kg & mg/kg \\
\hline Cultivated soil & 2 & Potatoes fruit & 7.32 & 23.29 & 3.18 & 3.18 \\
\hline Cultivated soil & 3 & Taro fruit & 10.21 & 9.13 & 0.89 & 0.89 \\
\hline Cultivated soil & 4 & Egg plant & 20.34 & 35.18 & 1.73 & 1.73 \\
\hline Cultivated soil & 5 & Faba bean & 4.20 & 24.46 & 5.82 & 5.82 \\
\hline
\end{tabular}

4/10- Quantification of soil pollution:

Soil pollution index ( SPI ) is used to quantify the degree of pollution of soil with respect to background . ( SPI ) can be calculated by two ways as given below :

4/10/1-Single Element Pollution Index ( SEPI ) :Used to evaluation methods and to identify single element contamination resulting in increased such metal toxicity. SEPI =metal content in soil /permissible level of metal. This suggested by Kloke ( 1997). and (Chen et al ., 2005) were reported as SEPI $\leq 1$ low contamination, $1<$ SEPI $\leq 3$ moderate contamination, SEPI $>3$ high contamination. 
Data in table (11) explain (SEPI) and ( CPI ) in the studied soil in Abu -Zaable area. In profile $1(\mathrm{Cu})$ is moderate contamination in surface and sub surface layers where (SEPI) $1.37 \mathrm{mg} / \mathrm{kg}$ and $1.17 \mathrm{mg} / \mathrm{kg}$ respectively but in third $(50-75 \mathrm{~cm})$ and deposit layers $(75-100)$ are low polluted where (SEPI) $0.25 \mathrm{mg} / \mathrm{kg}, 0.19 \mathrm{mg} / \mathrm{kg}$ respectively. Also in profile 2 its moderately contamination in the first three layers by $(\mathrm{Cu})$. Where is the ( SEPI ) < 3 .while in the deposit layer its low contamination by $(\mathrm{Cu})$ where (SEPI ) $0.63 \mathrm{mg} / \mathrm{kg}$.In profile 3 in the studied soil the surface and subsurface layers is highly contaminated by ( $\mathrm{Cu}$ ) where (SEPI ) > 3 .its equal $5.22,4.49 \mathrm{mg} / \mathrm{kg}$. While the third and deposit layers are low contamination by $(\mathrm{Cu})$ ( SEPI ) $<1$ its $0.67,0.68$ $\mathrm{mg} / \mathrm{kg}$ respectively. In profile 4 the surface and deposit layers are low contamination by copper where (SEPI) $<1$ its $0.67,0.30 \mathrm{mg} / \mathrm{kg}$. But in the subsurface and the third layers are moderately contaminated by $(\mathrm{Cu})$ where (SEPI) $1.33,1.09 \mathrm{mg} / \mathrm{kg}$ respectively. While in profile 5 all layers are moderately contaminated by copper where $<1$ (SEPI ) $<3$ its $1.45,1.29,2.41$ and $1.29 \mathrm{mg} / \mathrm{kg}$ respectively .

Table (11): Single pollution index(SEPI )and Combined pollution index ( CPI ) of heavy metals $(\mathrm{mg} / \mathrm{kg}$ ) in the studied soil .

\begin{tabular}{|c|c|c|c|c|c|c|c|c|c|c|c|c|}
\hline Prof. & Samp. & Depth. & SEPI of & CPI of & SEPI of & CPI of & $\begin{array}{c}\text { SEPI } \\
\text { of }\end{array}$ & CPI of & SEPI of & CPI of & SEPI of & CPI of \\
\hline No. & No. & (cm) & $\mathrm{Cu}$ & Cu. & $\overline{Z n}$ & Zn & Co & Co & $\mathbf{N i}$ & $\mathbf{N i}$ & $\mathrm{Cr}$ & $\mathrm{Cr}$ \\
\hline & 1 & $0-25$ & 1.37 & 0.27 & 0.38 & 0.08 & 0.46 & 0.09 & 0.84 & 0.17 & 1.22 & 0.25 \\
\hline & 2 & $25-50$ & 1.17 & 0.23 & 0.32 & 0.06 & 0.10 & 0.02 & 1.15 & 0.23 & 1.37 & 0.28 \\
\hline \multirow{2}{*}{$\begin{array}{c}\text { Cultivated } \\
\text { soil }\end{array}$} & 3 & $50-75$ & 0.25 & 0.05 & 0.24 & 0.05 & 0.18 & 0.04 & 0.60 & 0.12 & 0.55 & 0.11 \\
\hline & 4 & $75-100$ & 0.19 & 0.04 & 0.16 & 0.03 & 0.18 & 0.04 & 0.80 & 0.16 & 0.78 & 0.16 \\
\hline \multirow[t]{2}{*}{ 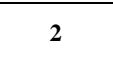 } & 5 & $0-40$ & 2.42 & 0.45 & 0.41 & 0.08 & 0.64 & 0.13 & 1.28 & 0.26 & 1.72 & 0.34 \\
\hline & 6 & $40-70$ & 1.97 & 0.39 & 0.32 & 0.06 & 0.85 & 0.17 & 1.23 & 0.25 & 1.53 & 0.31 \\
\hline \multirow{2}{*}{$\begin{array}{c}\text { Cultivated } \\
\text { soil }\end{array}$} & 7 & $70-100$ & 1.09 & 0.22 & 0.28 & 0.06 & 0.40 & 0.08 & 0.95 & 0.19 & 1.38 & 0.28 \\
\hline & 8 & 100- 120 & 0.63 & 0.13 & 0.23 & 0.05 & 0.40 & 0.08 & 0.51 & 0.11 & 1.20 & 0.24 \\
\hline & 9 & 0 - 30 & 5.22 & 1.04 & 0.31 & 0.06 & 0.82 & 0.16 & 1.81 & 0.36 & 3.39 & 0.68 \\
\hline & 10 & $30-60$ & 4.49 & 0.90 & 0.27 & 0.05 & 1.04 & 0.21 & 2.07 & 0.41 & 2.58 & 0.52 \\
\hline \multirow{2}{*}{$\begin{array}{c}\text { Cultivated } \\
\text { soil }\end{array}$} & 11 & $60-90$ & 0.67 & 0.13 & 0.19 & 0.04 & 0.40 & 0.08 & 0.83 & 0.17 & 1.20 & 0.24 \\
\hline & 12 & $90-150$ & 0.68 & 0.14 & 0.23 & 0.05 & 0.21 & 0.04 & 0.27 & 0.05 & 0.70 & 0.14 \\
\hline & 13 & 0 - 30 & 0.67 & 0.13 & 0.23 & 0.05 & 0.40 & 0.08 & 0.71 & 0.14 & 0.70 & 0.14 \\
\hline & 14 & $30-55$ & 1.33 & 0.27 & 0.30 & 0.06 & 0.43 & 0.09 & 0.33 & 0.07 & 1.04 & 0.21 \\
\hline \multirow{2}{*}{$\begin{array}{c}\text { Cultivated } \\
\text { soil }\end{array}$} & 15 & $55-80$ & 1.09 & 0.22 & 0.19 & 0.04 & 0.53 & 0.11 & 0.50 & 0.10 & 1.22 & 0.24 \\
\hline & 16 & $80-120$ & 0.30 & 0.06 & 0.13 & 0.03 & 0.38 & 0.08 & 0.42 & 0.08 & 0.67 & 0.13 \\
\hline 5 & 17 & 0 - 30 & 1.45 & 0.29 & 0.36 & 0.07 & 0.64 & 0.13 & 0.82 & 0.16 & 1.20 & 0.24 \\
\hline \multirow{2}{*}{$\begin{array}{c}\text { Cultivated } \\
\text { soil }\end{array}$} & 18 & $30-50$ & 1.29 & 0.26 & 0.36 & 0.07 & 0.42 & 0.08 & 0.77 & 0.15 & 1.35 & 0.27 \\
\hline & 19 & $50-80$ & 2.41 & 0.48 & 0.54 & 0.11 & 0.70 & 0.14 & 1.64 & 0.33 & 1.43 & 0.29 \\
\hline 6 & 20 & $80-100$ & 1.29 & 0.26 & 0.21 & 0.04 & 0.26 & 0.05 & 0.51 & 0.11 & 1.19 & 0.24 \\
\hline $\begin{array}{c}\text { P.M. ofM } \\
\text { metal }\end{array}$ & $/ / \mathbf{K}$ & & 3 & & 0 & & 5 & & 4.00 & & 6.00 & \\
\hline
\end{tabular}

In all profiles in the studied soils in Abu -Zaabal area are low contaminated by Zinc ( Zn) where ( SEPI ) $<1$. as (Chen .et al . ,2005) has reported.All layers in the studied profiles are low contaminated with 
Co where the (SEPI ) less than 1 except the subsurface layer in the profile 3.where (SEPI) more than 1 its $1.04 \mathrm{mg} / \mathrm{kg}$.

For Ni metal in profile 1 the values of (SEPI) in all layers less than 1.excpt subsurface layer ( SEPI ) $1.15 \mathrm{mg} / \mathrm{kg}$ its moderate contaminated by $\mathrm{Ni}$.But in profile 2 (SEPI) in the surface and subsurface layers more than 1 So this two layers is moderately contaminated by Nickel metal. while the third and deposit layers are low contaminated by $\mathrm{Ni}$ metal where the (SEPI) $<1$. Also in profile 3 in the studied area the first and the second layers is moderately contaminated by Ni where ( SEPI ) more than 1 its $1.18,2.07 \mathrm{mg} / \mathrm{kg}$ respectively. While the third and deposit layers are low contaminated with Ni metal where (SEPI ) $<1$. All layers in profiles 4, 5 in the studied area are low contaminated with $\mathrm{Ni}$ metal. Where (SEPI) less than 1. For ( $\mathrm{Cr})$ metal in profile 1. the first and the second layers where (SEPI) $>1$ So this layers are moderate contamination by Chromium metal .But in the third and deposit layers the (SEPI ) $<1$ and this layers are low contaminated by $(\mathrm{Cr})$ metal .All layers in profiles 2, 5 .where (SEPI ) more than 2 So these layers are moderately contaminated by $\mathrm{Cr}$ metal . But in profile 3 the surface layer is highly contaminated by $(\mathrm{Cr}$ ) where (SEPI ) more than 3 its $3.39, \mathrm{~g} / \mathrm{kg}$ while the subsurface and the third layers are moderate contaminated by (Cr) metal where (SEPI ) more than 1 its $2.58 \mathrm{mg} / \mathrm{kg} 1.20 \mathrm{mg} / \mathrm{kg}$.while the deposit layer is low contaminated by $\mathrm{Cr}$ metal. In profile 4 the surface and deposit layers are low contaminated by $\mathrm{Cr}$ metal where (SEPI ) less than 1 .while the sub surface and the third layers are moderate contaminated by Cr metal Where (SEPI ) $1.04,1.22 \mathrm{mg} / \mathrm{kg}$ respectively.

\section{4/10/2-Combined pollution index:}

The concept of a combined pollution index (CPI) which was used as another common evaluation methods of trace metals accumulation and to identify multi-element contamination resulting in increased overall metal toxicity .The CPI is calculated by the equation (SEPI ) / NO. of metals in the study (the number of metals in this study its five metals) and then classified as low $(\mathrm{CPI} \leq 1)$ middle $(1<\mathrm{CPI} \leq 2)$ or high $(\mathrm{CPI}>$ 2). (Chen, 2005).

All layers in all profiles of the studied soils the combined pollution index less than 1 . So are low contamination by the heavy metals in this study ( $\mathrm{Cu}, \mathrm{Cr}, \mathrm{Zn}, \mathrm{Ni}$, and $\mathrm{Co}$ ) except $(\mathrm{Cu})$ metal in the surface layer ( 0 - $30 \mathrm{~cm}$ ) in profile 3.the (CPI ) more than 1. its moderately contaminated by copper where (CPI) equal $1.04 \mathrm{mg} / \mathrm{kg}$. 
In brief, the single and combined indices of metals contamination in soils suggest that with trace metals. This does not preclude the main role of parent material from which soils are derived and the sedimentation, regime of soil matrix anthropogenic inputs contributed, to a great extent, to the accumulation and contamination in the study area. Therefore, continuous environmental monitoring of the study area is needed and amelioration treatments to minimize or inactivate their mobility and reactivity should be practiced to eliminate the toxic effect of trace metals in soils and grown crops which are the main pathway to animals and humans.

\section{5-CONCLUSION}

In the present study, we can concluded that:

1- The trace metals content in soil dependent on soil physico- chemical properties. The total, chemical extractable and plants grown in soil concentration of heavy metals in the studied area take these sequences $\mathrm{Cr}>\mathrm{Cu}>\mathrm{Zn}>\quad \mathrm{Ni}>\mathrm{Co} . \mathrm{Cu}>\mathrm{Cr}>\mathrm{Zn}>\mathrm{Ni}>\mathrm{Co}$ and $\mathrm{Zn}>\mathrm{Cu}>\mathrm{Cr}>\mathrm{Ni}>\mathrm{Co}$. receptively.

2- All trace metals can be transported from soil and accumulate in vegetables tissues leads to contamination it causes a public healthy hazard.

3- $\mathrm{TF}$ of all Trace metals ranges from $1>\mathrm{TF}>1$, The soil in the studied area contaminated with varying degrees of low ,moderate and high pollution. Also $1>\mathrm{BAF}>1$ in vegetables and occur accumulation according this order Onion plant > Egg plant > Faba bean > Potatoes fruit $>$ Taro fruit.

4- $1>$ SEPI $>3$, CPI $<1$ the soil in the studied area contaminated by heavy metals by varying degrees of low ,moderate and high pollution with exception of $\mathrm{Cu}$ metal its moderately contaminated

5-All these results indicate that the waste generated from the Abu Zaabal Fertilizer Factories caused pollution to the lands and growing plants.

\section{REFERENCE}

Abou El- Nour, F.H. ; M.A. Helayel and A. Kandil (2004). Heavy metal pollutants released from Abu- Zaabal and $10^{\text {th }}$ of Ramadan industrial regions in Egypt. The Egyptian Society of Nuclear Sciences and Applications, Cairo (Egypt),750 (8):270 - 279.

Asaolu, S.S., (1995). Lead content of vegetables and tomatoes at Erekesan market. Pakistan J. Sci. Ind. Res., 38: 399-40. Food Agricultural Organization/World Health Organization (FAO/WHO) Standards, (2001). Codex Alimentarius Commission, Rome. 
Ashok, K. ; B.S. Bisht ; K. Manish and K. Lalit (2010). Effect of Ni and on growth Vigna Mungo Vigna Rrdiata and Glycinemax. Int.J pharm and Bio sciences ,1 (2

Bhatt, S.S. ; V. Sambyal and A.K. Nagpal (2016). Heavy metals bioaccumulation in Berseem (Trifolium alexandrinum) cultivated in areas under intensive agriculture .Punjab ,.India. Springer Plus, Pp: 173 -184 .

Black, C.A. (1983)."Methods of soil analysis".Part 1. Agron series (9)Am. Soc. Agron. Mad. Wise., U.S.A.

Blalyock, M.J. and J.W. Huang (2005). Pytoextraction of metals in pyoremediation of toxic metals using plant to clean up the environment. (Eds.: I. Raskin, B.D. Ensley viley, New York, 53 - 7.

Chen, Y. ; Y.G. Luo ; Y.G. Hu ; Z.X. Zhu and Z.Y. He (2005). Study of chemical behaviour of chromium in soils. factors affecting $\mathrm{Cr}$ (I) adsorption and precipitation in soils. Acta pedagogical Sinica, 31(1): $77-85$.

El-Bahi S.M. ; N.W. El-Dine ; A. El-Shershaby and A. Sroor (2004). Elemental analysis of Egyptian phosphate fertilizer components. Health phys. Mar; 86(3):303-7.

Elwa, A.M. (2016). Distribution ,partitioning and speciation of some trace metals in cultivated desert soils in the $10^{\text {th }}$ of Ramadan region.ph..D .thesis. Fac Sci. Benha Univ.,Egypt.

Gad, A. ; H.K. Garamoon ; M.H. Abd El-Aal and N.M. Afify (2018). Groundwater deterioration with heavy metals in north east Cairo area. Egypt. J. Environ. Sci., 41(1):39-60.

Guan, T.X. ; H.B. He ; X.D. Zhang and Z. Bai (2011). Cu fractions, mobility and bioavailability in soil-wheat system after $\mathrm{Cu}-$ enriched livestock manure applications. Chemosphere, 82: 215222.

Hesse, P.R. (1971). A textbook on soil chemical analysis. William Clowe and Sons Limited, London.

Jackson, M.L. (1973). Soil chemical analysis. Prentice -Hall, Inc England Clif, New Jersey, U.K.

Kabata-Pendias, A. and H. Pendias (2001). Trace elements in soils and plants. 3rd edition. CRC Press, Boca Raton, Florida, 413 pp.

Khan, A. ; S. Khan ; M.A. Khan ; Z. Qaar and M. Waqas (2015). The up take and bioaccumulation of heavy metals by food plants. Environmental Science and pollution Research, 22: 13772 - 13799. 
Kloke, A. ; D.R. Sauerbeck and H. Vetter (1997). The Contamination of plants and soil with heavy metals and the transport of metals in terrestrial food chain. In Nriagu, J.O.(Ed.).Changing Metals Cycles and Human Health. Springer - Verlag, Berlin ., Germany.

Lindsay, W.L. and W.A. Norvell, (1978). Development of a DTPA soil test for zinc, iron, manganese, and copper. Soil Science Society of America Journal, 42: 421-428.

Ma, L. ; K.M. Qi ; C. Komar ; W. Zhang ; Y. Cai and E.D. Kennelley (2001). A fern that hyper accumulators arsenic. Nture, 409: 579 - 585.

Nicholson, N.(1984): A Theory of Work Role Transitions. Administrative Science Quarterly, 29(2): 172-191.

Noufal, E.H. ; H.M. Salem ; M.A. Abdel-Salam ; M.S. Soliman ; E.A. Kotb ; E.A. Shehab and A.H. Solieman (2015). Monitoring Some Heavy Metal Contaminants in soils of Some Sites at Qalubiya Governorate. environmental sciences (S54).

Okamoto, K. ; Y. Yamamoto and K. Fuwa (1978). Accumulation of manganese, zinc, cobalt, nickel and cadmium by Clethra barbinervis. Agric. Biol. Chem., 42: 663-664.

Piper, C.S. (1950).Soil and plant analysis Waite Agric .Res. Inst. Adelaid S .A., Australia

Wahla, I.H. and M.B. Kirkham (2008). Heavy metal displacement in salt-water - irrigated soil during phytoremediation . Environ Pollut, 155: 271 - 283.

WHO, World Health Organization (2001). Environmental Health Criteria for Zinc, Available from: http://www.inchem.org/documents/ehc/ehc/ehc221.htm. Accessed 2004 September 13 [Google Scholar]

WHO, (2011). Evaluation of certain contaminants in food: seventysecond report of the Joint FAO/WHO Expert Committee on Food Additives. WHO Technical Report Series, No. 959. WHO, Geneva,105.pp.
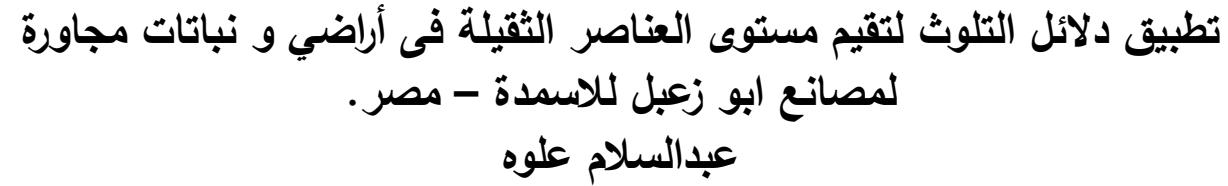

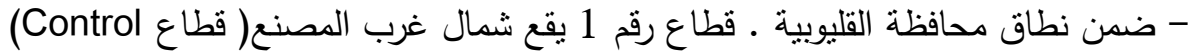
وباقى القطاعات تقع جنوب شرق المصنع 
2- بدراسة الخواص الطبيعية والكيميائية للتربة اسفرت النتائج عما يلي:-

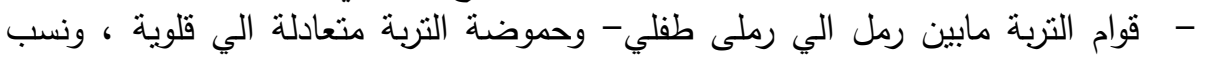

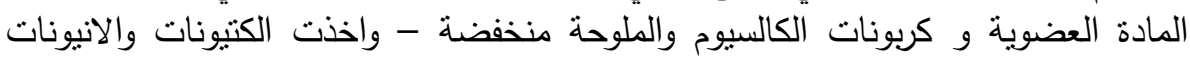

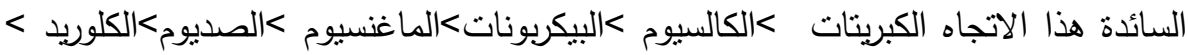

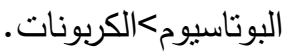

3- أجريت الدراستة على خمسة عناصر صغرئ فئ في الاراضى المدروسة وهى عناصر ثقيلة

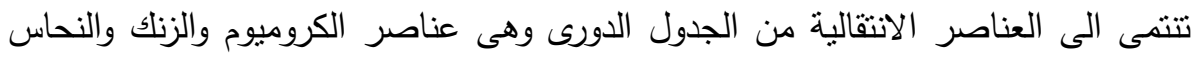
والكوبلت والنيكل.

4- وكان المحتوى الكلى لعناصر الدراسة بزيد في هذا الاتجاه: الكروميوم >النحاس >الزناسكا

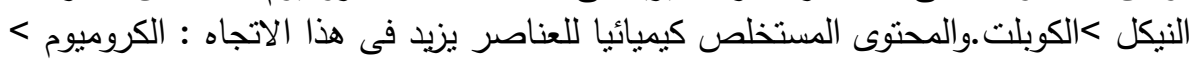
النحاس> الزنك>> النيكل> الكوبلت >

5- وكان محتوى الخضروات النباتية من العناصر التقبلة يزيد فى هذالاتجاه الزنكا> النحاس>

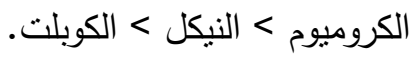

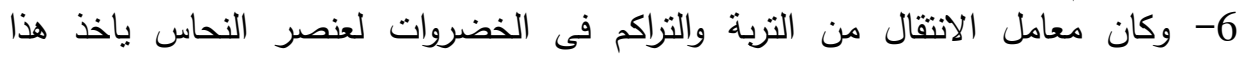

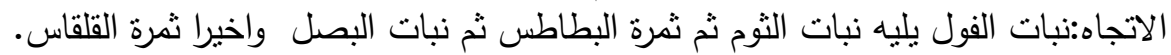

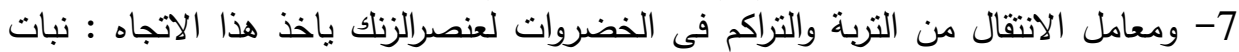

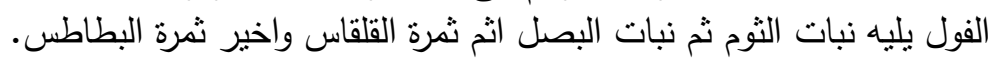

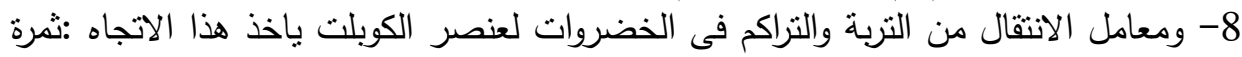

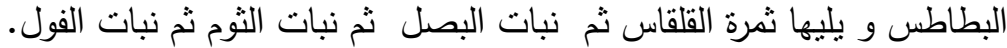

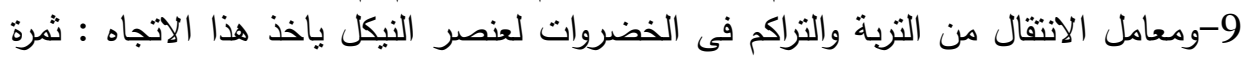

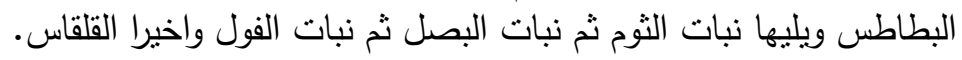

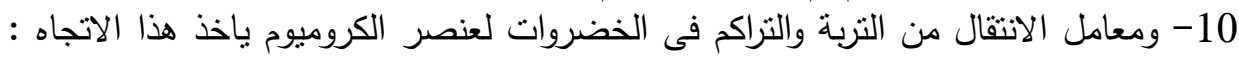

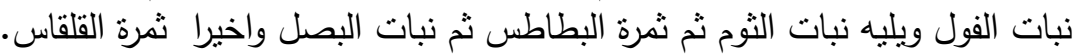

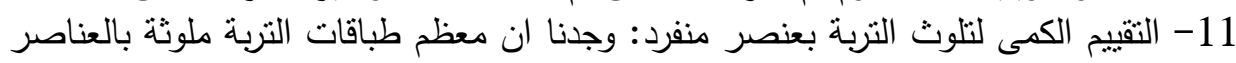

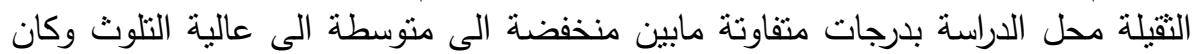

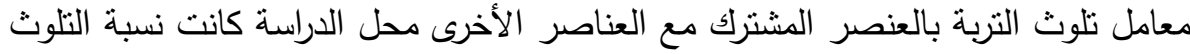
لقطاعات التربة منخفضة ماعدا عنصر النحاس كان في طبقة واحدة متوسطة التلوث به. 